Rev. Int. Contam. Ambie. 34 (2) 203-213, 2018

DOI: $10.20937 /$ RICA.2018.34.02.02

\title{
BACTERIAL COMMUNITIES OF THE OYSTERS Crassostrea corteziensis AND C. sikamea OF COSPITA BAY, SINALOA, MEXICO
}

\author{
Irasema E. LUIS-VILLASEÑOR ${ }^{1 *}$, Olga O. ZAMUDIO-ARMENTA ${ }^{1}$, Domenico VOLTOLINA ${ }^{2}$, \\ Jesús A. ROCHIN-ARENAS ${ }^{1}$, Bruno GÓMEZ-GIL ${ }^{3}$, Juan M. AUDELO-NARANJO ${ }^{1}$ y \\ Francisco A. FLORES-HIGUERA ${ }^{1}$
}

\footnotetext{
${ }^{1}$ Universidad Autónoma de Sinaloa, Facultad de Ciencias del Mar, Paseo Claussen s/n, Mazatlán, Sinaloa, México

${ }^{2}$ Centro de Investigaciones Biológicas del Noroeste, Apartado 1132, Mazatlán, Sinaloa, México

${ }^{3}$ Centro de Investigación en Alimentación y Desarrollo, Unidad Mazatlán, Apartado 711, Mazatlán, Sinaloa, México

*Author for correspondence; irasemaluis@uas.edu.mx
}

(Received December 2016; accepted September 2017)

Key words: bacteria, cultured oysters, wild oysters

\begin{abstract}
This work aimed to quantify the bacterial loads and determine the taxonomic composition of the microbial communities of oysters Crassostrea corteziensis and C. sikamea, as well as the surrounding waters of Cospita Bay, using two sets of samples (M1 and M4) obtained in the dry season and two (M2 and M3) in the rainy season. Bacterial loads were quantified with the viable count technique and out of the 320 strains isolated for their different morphologies, 84 were identified with molecular techniques to the species level. These species pertained to the families Vibrionaceae, Bacillaceae, Brucellaceae, Micrococcaceae, Pseudoalteromonaceae, Rhodobactereceae, Shewanellaceae and Staphylococcaceae. The higher concentrations of total bacteria were in the rainy season (samples M2 and M3), when families Vibrionaceae and Brucellaceae dominated. The highest Vibrio spp. and Pseudomonas spp. concentrations were in winter (samples M4). Probably because of its poor health conditions, the Kumamoto oyster $C$. sikamea had the highest diversity of bacterial species and the highest number of known pathogens for aquatic organisms.
\end{abstract}

Palabras clave: bacterias, ostiones cultivados, ostiones silvestres

\section{RESUMEN}

En la presente investigación se cuantificó la carga bacteriana y se determinó la composición de la microbiota de los ostiones Crassostrea corteziensis y C. sikamea, así como del agua circundante de Bahía Cospita, usando dos muestras obtenidas durante el periodo de estiaje (muestreos M1 y M4) y dos obtenidas en el periodo de lluvias (muestreos M2 y M3). La carga bacteriana se cuantificó con la técnica de cuenta viable y se aislaron con criterios morfológicos 320 cepas, de las cuales de 84 se identificaron con técnicas moleculares hasta el nivel de especie y fueron agrupadas en las familias Vibrionaceae, Bacillaceae, Brucellaceae, Micrococcaceae, 
Pseudoalteromonaceae, Rhodobactereceae, Shewanellaceae y Staphylococcaceae. La mayor concentración de bacterias totales se presentó en la temporada de lluvias (muestreos M2 y M3), predominando las familias Vibrionaceae y Brucellaceae. La mayor concentración de Vibrio spp. y Pseudomonas spp. se presentó en invierno (muestreo M4). El ostión Kumamoto (C. sikamea) presentó una mayor diversidad de especies y el mayor número de bacterias patógenas para organismos acuáticos, que es un probable reflejo de su estado de salud deficiente.

\section{INTRODUCTION}

The yearly growth rate of bivalve culture in Mexico is close to $1.2 \%$ (CONAPESCA 2013), and has been limited by frequent mortalities caused by infectious diseases of different origin, such as the phenomenon known as summer mortality syndrome. This has been associated with the presence and virulence of pathogenic bacteria, or of herpesvirus OsHV1 (Samain and McCombie 2008, Cáceres-Martínez and Vázquez-Yeomans 2013, Petton et al. 2015). Most of these diseases are related to factors that favor pathogens growth, such as excessive densities or poor feeding conditions (Trabal-Fernández et al. 2014).

Other factors generally associated to mortality outbreaks are high temperatures, low oxygen availability or excessive energetic expenditures, mainly associated to spawning (Cheney et al. 2000, Li et al. 2007, de Decker and Saulnier 2011). There are several studies on the composition and seasonal variations of the bacterial communities associated to bivalve molluscs (Llanos et al. 2002, Romanenko et al. 2008). Some of these studies stress the role of several species of the genus Vibrio, which may affect larvae, juveniles and adults of several aquatic organisms, including oysters, mussels, clams and scallops (Paillard et al. 2004, Beaz-Hidalgo et al. 2010).

In particular, $V$. splendidus and $V$. aestuarianus have been associated to the summer mortalities that affect oyster production worldwide (Gay et al. 2004, Garnier et al. 2007, 2008, Labreuche et al. 2010). These and several other Vibrio species, in particular $V$. parahaemolyticus, are also important vectors of food-borne diseases for marine shellfish consumers (Daniels et al. 2000, McLaughlin et al. 2005, GarcíaLázaro et al. 2010, Kokashvili et al. 2015).

This indicates the importance of gaining better knowledge on the composition and seasonal variations of the bacterial communities associated to cultured and wild populations of commercially important bivalves.

The cultivable Vibrio flora harbored in healthy oysters is a bivalve-specific community with densities ranging from $10^{2}$ to $10^{4}$ colony forming units (CFU)/ mg of tissues, and higher loads may be expected at higher temperatures (Saulnier et al. 2010). However, if bacterial concentrations are too high, they may induce negative stress, with consequent high mortalities and low condition indices (Harekrishna et al. 2014). Additionally there is a general lack of information on the structure and persistence of the bacterial community present in wild and cultivated oysters of commercial interest, such as $C$. corteziensis and C. sikamea.

This study aimed to determine the concentration and taxonomy of culturable heterotrophic bacteria present in the oysters Crassostrea corteziensis and C. sikamea cultured in Cospita Bay, Sinaloa, NW Mexico, and of the bacterioflora suspended in the surrounding water.

\section{MATERIALS AND METHODS}

Cospita Bay lies within coordinates $24^{\circ} 04^{\prime} 30^{\prime \prime}$ to $24^{\circ} 05^{\prime} 65^{\prime \prime} \mathrm{N}$ and $107^{\circ} 08^{\prime} 42^{\prime \prime}$ to $107^{\circ} 08^{\prime} 06^{\prime \prime} \mathrm{W}$. Samples were obtained at quarterly intervals from May 2014 to January 2015. Two sets were from the dry period (M1: dry-hot, May 7th 2014; and M4: dry-cold, January 7th, 2015), and two from the warm-rainy season (M2 and M3, August 29th and October 1st, 2014). Samples of C. corteziensis and C. sikamea (30 of each species) were donated by a local commercial oyster farm. Wild $C$. corteziensis (30, from roots of different mangroves) and several water samples (mixed in equal parts to give one- $\mathrm{L}$ composite sample) were also obtained in sterile containers from areas surrounding each sampling point. Surface salinity, temperature and oxygen concentration were determined in situ in the central area of the oyster farm using a refractometer and an YSI 55 dissolved oxygen meter.

Oyster and water samples were transported in ice boxes $\left(<7^{\circ} \mathrm{C}\right)$ to the laboratory, where $100 \mu \mathrm{L}$ of the original water sample and of its 1:10 dilution were spread plated in triplicate on Zobell medium for total culturable marine bacteria (2216), on cetrimide 
Pseudomonas medium and on $2.5 \% \mathrm{NaCl}$-added TCBS for Vibrio-like bacteria detection. DIFCO media were used for all isolation and purification work.

Oysters were thoroughly washed and brushed under running tap water, rinsed with sterile distilled water (DW) and each sample of 30 oysters was divided into five groups of six oysters chosen at random. The oysters of each group were shucked and the liquor and soft parts were homogenized for $90 \mathrm{~s}$ in $450 \mathrm{~mL}$ of $3 \%$ saline solution using a sterile food blender. The resulting suspension was used to prepare four serial dilutions $\left(10^{-2}\right.$ to $\left.10^{-5}\right)$, which were spread-plated $(100 \mu \mathrm{L})$ in the same growth media used for water samples. All plates were read after $48 \mathrm{~h}$ at $30 \pm 2{ }^{\circ} \mathrm{C}$ and the results served to calculate bacteria concentrations in seawater $(\mathrm{CFU} / \mathrm{mL})$ and in the oysters' soft tissues (CFU/g, wet weight).

Colonies with different morphologies, spreadplated on the respective growth medium, were purified with the cross streak technique. Five-six colonies were preserved in $1.5 \mathrm{~mL}$ Eppendorf vials with $1 \mathrm{~mL}$ of $96 \%$ ethanol, and used later for their identification using molecular techniques. The original purified colonies were considered pure strains, assigned an identification key and preserved in glycerol at $-80^{\circ} \mathrm{C}$ in the laboratory's bacterial cultures collection.

For species identification, the DNA of each ethanol-preserved strain was extracted with the Wizard ${ }^{\circledR}$ Genomic DNA Purification Kit (lot A1120, Promega). After adjusting concentration to $50 \mathrm{ng} / \mu \mathrm{L}$, the ribosomal $16 \mathrm{~S}$ gene (16S ARNr) was amplified using end-point polymerase chain reaction (PCR) and universal primers Forward 27f.1 (AGR GTT TGA TCM TGG CTC AG) and Reverse 1492R2 (GGT TAC CTT GTT ACG ACT T). The amplification program was: $16 \mathrm{~S}: 94^{\circ} \mathrm{C} / 2{ }^{\prime} \rightarrow 35$ cycles $\left(94^{\circ} \mathrm{C} / 1\right.$ ' $\left.\rightarrow 56{ }^{\circ} \mathrm{C} / 1^{\prime} \rightarrow 72^{\circ} \mathrm{C} / 1^{\prime}\right) \rightarrow 72{ }^{\circ} \mathrm{C} / 5^{\prime} \rightarrow 4{ }^{\circ} \mathrm{C} / \propto$.

The products obtained were sequenced at Macrogen (Republic of Korea), and the sequences obtained were used for species identification with the public databases BLAST (Altschul 1997) and EzTaxon (Chun et al. 2007).

The sequences obtained in FASTA format were aligned with program ClustalW (Thompson et al. 1994). The alignments were exported to version 5.0 of the program MEGA andin order to obtain the molecular phylogenetic tree of each strain (Tamura et al. 2011). Tusing the neighbor-joining test (NJ) (Saitou and Nei 1987) with the p-distance method and 500 bootstrap repetitions was used to that end, considering transitions and transversions. The bacterium Klebsiella pneumonia served as outgroup.

All bacterial concentrations, transformed to the respective R1 rank values (Conover 2012), were normal and homoscedastic (KolmogorovSmirnov and Bartlett's tests). Therefore, the mean concentrations of the bacteria present in the water samples, determined with each of the three growth media in the four sampling dates, were compared using one-way ANOVA tests, separating the different means with Tuckey's tests. Those of the bacteria present in wild and cultured oysters were compared with two-ways ANOVA and Tuckey's tests. All statistical tests were performed with SigmaPlot 11.0 software. In all cases, the significance level was $\alpha=0.05$ (Zar 1996).

\section{RESULTS}

Temperature and salinity values ranged from 32.3 to $23.2{ }^{\circ} \mathrm{C}$ and 35.0 to $23.2 \mathrm{ppt}$, respectively. In both cases, differences were significant. Oxygen concentrations were significantly higher in the first two sampling dates than in the remaining samplings ( 8.09 and 7.46 , compared to 4.87 and $5.35 \mathrm{mg} / \mathrm{L}$ ). In all cases differences were not clearly related to climatic events (Table I).

TABLE I. MEAN $\left( \pm\right.$ SD) TOTAL MARINE AND Vibrio-LIKE BACTERIA CONCENTRATIONS IN $10^{3}$ COLONY FORMING UNITS/mL (CFU/mL), AND MEAN TEMPERATURE, SALINITY AND DISSOLVED OXYGEN OF THE WATER SAMPLES OBTAINED IN COSPITA BAY ON THE FOUR SAMPLING DATES

\begin{tabular}{|c|c|c|c|c|c|}
\hline \multirow{2}{*}{ Sampling } & \multirow{2}{*}{$\begin{array}{c}\text { Temp. } \\
\left({ }^{\circ} \mathrm{C}\right)\end{array}$} & \multirow{2}{*}{$\begin{array}{c}\text { Salinity } \\
\text { (ppt) }\end{array}$} & \multirow{2}{*}{$\begin{array}{c}\mathrm{O}_{2} \\
(\mathrm{mg} / \mathrm{L})\end{array}$} & \multicolumn{2}{|c|}{$\mathrm{CFU} / \mathrm{mL}$} \\
\hline & & & & Total* & Vibrio \\
\hline (M1) Dry-warm & $27.5 \pm 0.3^{\mathrm{ab}}$ & $35.0 \pm 1.0^{\mathrm{a}}$ & $8.09 \pm 1.8^{\mathrm{a}}$ & $0.87 \pm 0.25^{\mathrm{a}}$ & $0.31 \pm 0.18^{\mathrm{ab}}$ \\
\hline (M2) Wet-warm & $32.3 \pm 0.2^{\mathrm{a}}$ & $23.2 \pm 1.5^{\mathrm{b}}$ & $7.46 \pm 2.1^{\mathrm{a}}$ & $3.92 \pm 2.87^{\mathrm{a}}$ & $0.13 \pm 0.12^{b}$ \\
\hline (M3) Wet-warm & $28.2 \pm 0.5^{\mathrm{ab}}$ & $33.5 \pm 0.7^{\mathrm{a}}$ & $4.87 \pm 0.9^{b}$ & $2.36 \pm 1.75^{\mathrm{a}}$ & $0.14 \pm 0.13^{\mathrm{ab}}$ \\
\hline (M4) Dry-cold & $23.2 \pm 0.3^{\mathrm{b}}$ & $33.3 \pm 0.9^{\mathrm{a}}$ & $5.35 \pm 1.1^{\mathrm{b}}$ & $8.77 \pm 0.10^{\mathrm{a}}$ & $0.87 \pm 0.35^{\mathrm{a}}$ \\
\hline
\end{tabular}

* Non parametric test. Different letters indicate significant differences between data in the same column $(\mathrm{p}=0.05$, $a \geq a b \geq b$ and $a>b)$ 
The concentrations of culturable marine bacteria ranged from 875 to $3920 \mathrm{CFU} / \mathrm{mL}$, and there were no differences between sampling dates. Those of Vibriolike bacteria varied from 127.50 to $875 \mathrm{CFU} / \mathrm{mL}$. These were significantly different, and were determined in M2 and M4 samples, respectively (Table I). The cetrimide medium gave negative results in all water samples.

The concentrations of total marine bacteria tended to be higher in the samples of the rainy than in the dry season, although with overlapping values in dry-cold samples of $C$. corteziensis and dry-warm samples of C. sikamea, respectively (Table II). The tendency was similar in the case of Vibrio-like bacteria. For C. corteziensis differences between rainy and dry seasons were significant in all cases, while for $C$. sikamea the lowest and highest values were observed in the samples of the dry-warm and dry-cold season, respectively (Table II).

Pseudomonas showed the same species-related trends. The lowest and highest mean annual values were recorded in the dry-warm and dry-cold samples in $C$. sikamea, while in C. corteziensis mean concentrations were higher in the rainy than in the dry season samples (Table II).

In the available samples of the dry period (M1 and M4), bacterial loads were significantly lower in cultured than in wild oysters. In these, marine and Vibrio-like bacteria were significantly higher in the dry-cold, rather than in the dry-warm samples. In cultured oysters, there were no differences between the mean concentrations of Pseudomonas and marine bacteria in samples obtained in the warm or in the cold period while that of Vibrio-like bacteria was significantly higher in the dry-cold samples (Table III).
TABLE III. MEAN $( \pm$ SD) BACTERIAL CONCENTRATIONS $\left(10^{3} \mathrm{CFU} / \mathrm{g}\right)$ OF CULTURED AND WILD Crassostrea corteziensis OF COSPITA BAY IN THE SAMPLES OF THE DRY SEASON M1 (WARM) AND M4 (COLD)

\begin{tabular}{lcr}
\hline & Cultured & \multicolumn{1}{c}{ Wild } \\
\hline & Marine bacteria \\
M1 Dry-warm & $1.86 \pm 0.62^{\mathrm{c}}$ & $34.20 \pm 18.84^{\mathrm{b}}$ \\
M4 Dry-cold & $3.82 \pm 0.50^{\mathrm{c}}$ & $1416.66 \pm 381.88^{\mathrm{a}}$ \\
\hline \multicolumn{3}{c}{ Vibrio } \\
M1 Dry-warm & $0.08 \pm 0.08^{\mathrm{d}}$ & $1.05 \pm 0.74^{\mathrm{b}}$ \\
M4 Dry-cold & $0.51 \pm 0.24^{\mathrm{c}}$ & $40.99 \pm 0.00^{\mathrm{a}}$ \\
\hline & Pseudomonas & \\
M1 Dry-warm & $0.04 \pm 0.02^{\mathrm{b}}$ & $0.57 \pm 0.16^{\mathrm{a}}$ \\
M4 Dry-cold & $0.06 \pm 0.06^{\mathrm{b}}$ & $2.88 \pm 3.72^{\mathrm{a}}$ \\
\hline
\end{tabular}

Different letters indicate significant differences $(p=0.05, a>$ $\mathrm{b}>\mathrm{c}>\mathrm{d}$ )

CFU: colony forming units

\section{Bacteria identification}

The number of strains isolated for their morphologies was notably lower in the dry (cold + warm) (M1 $+\mathrm{M} 4=95)$ than in the rainy season $(\mathrm{M} 2+\mathrm{M} 3=$ 225 ) samplings. Among these, molecular techniques allowed identification of 84 sequences with $90-100 \%$ similarity to those of taxonomic entities available in public databases (Fig. 1).

The families identified in M2 and M3 samplings in both oyster species were Vibrionaceae, Bacillaceae, Brucellaceae, Micrococcaceae, Pseudoalteromonaceae, Rhodobactereceae and Staphylococcaceae, and the most frequent was Vibrionaceae (76 and $71 \%$ of all sequences observed in M2 and M3,

TABLE II. MEAN ( \pm SD) BACTERIAL CONCENTRATIONS (IN $10^{3} \mathrm{CFU} / \mathrm{mL}$ ) OF Crassostrea corteziensis AND C. sikamea DETERMINED ON THE FOUR SAMPLING DATES M1 TO M4 IN COSPITA BAY

\begin{tabular}{lcccc}
\hline & M1 & M2 & M3 & M4 \\
\hline & \multicolumn{5}{c}{ Marine bacteria } \\
C. corteziensis & $1.86 \pm 0.62^{\mathrm{b}}$ & $7.20 \pm 6.88^{\mathrm{ab}}$ & $31.88 \pm 17.60^{\mathrm{a}}$ & $3.82 \pm 0.50^{\mathrm{b}}$ \\
C. sikamea & $0.71 \pm 0.36^{\mathrm{b}}$ & $20.60 \pm 12.86^{\mathrm{a}}$ & $18.93 \pm 14.11^{\mathrm{a}}$ & $9.99 \pm 1.00^{\mathrm{ab}}$ \\
\hline \multicolumn{5}{c}{ Vibrio } \\
C. corteziensis & $0.15 \pm 0.05^{\mathrm{c}}$ & $4.15 \pm 3.27^{\mathrm{b}}$ & $12.35 \pm 11.45^{\mathrm{b}}$ & $0.51 \pm 0.24^{\mathrm{c}}$ \\
C. sikamea & $0.06 \pm 0.03^{\mathrm{c}}$ & $14.88 \pm 11.44^{\mathrm{b}}$ & $13.86 \pm 9.03^{\mathrm{ab}}$ & $27.33 \pm 2.71^{\mathrm{a}}$ \\
\hline & \multicolumn{3}{c}{ Pseudomonas } \\
C. corteziensis & $0.06 \pm 0.01^{\mathrm{bc}}$ & $0.30 \pm 0.15^{\mathrm{b}}$ & $0.07 \pm 0.01^{\mathrm{b}}$ & $0.03 \pm 0.02^{\mathrm{c}}$ \\
C. sikamea & $0.02 \pm 0.01^{\mathrm{c}}$ & $0.38 \pm 0.20^{\mathrm{b}}$ & $0.18 \pm 0.14^{\mathrm{abc}}$ & $2.28 \pm 0.23^{\mathrm{a}}$ \\
\hline
\end{tabular}

Different letters indicate significant differences between data in the same row $(p=0.05, a>b)$ CFU: colony forming units 


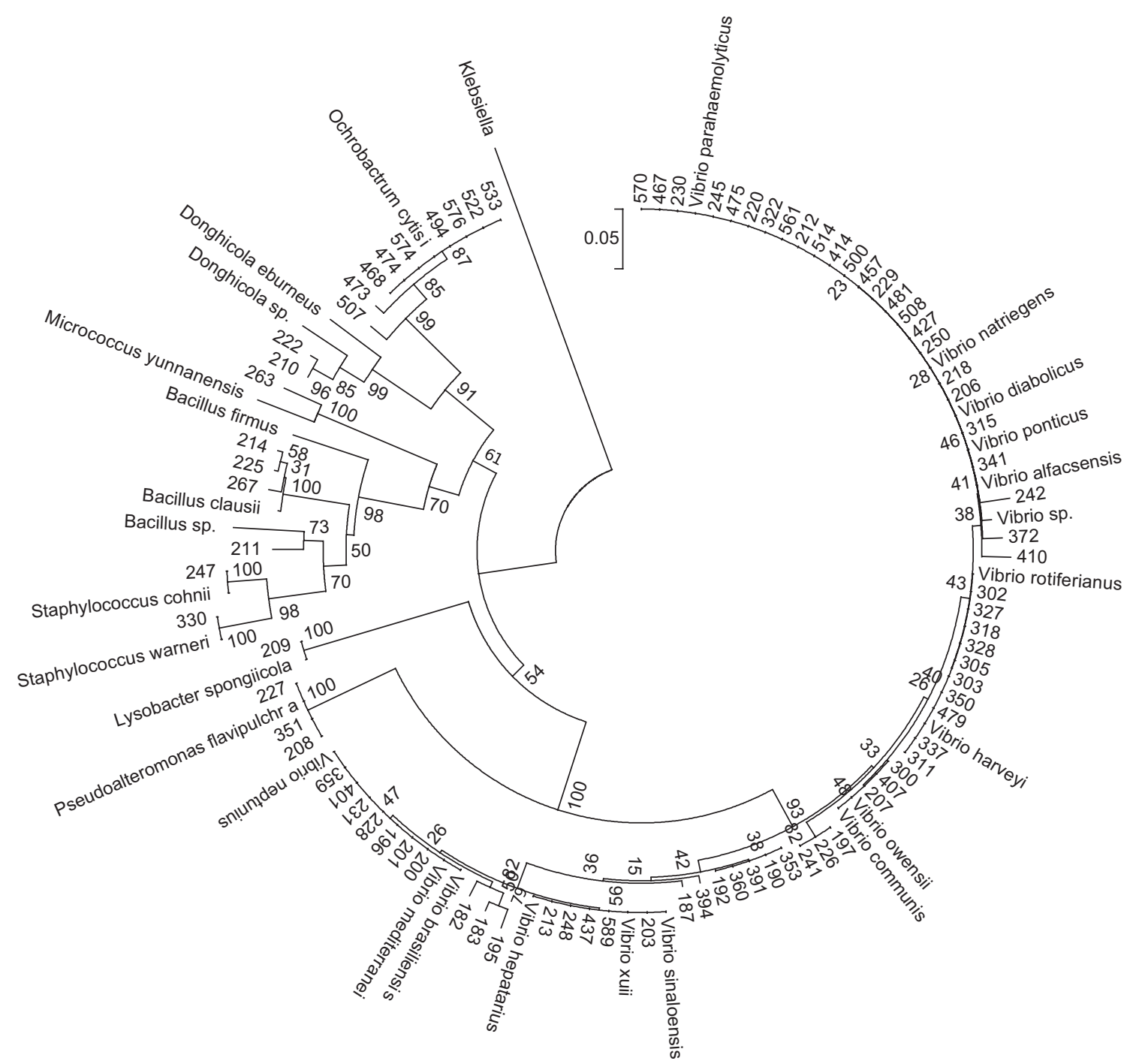

Fig. 1. DNA 16s-based phylogenetic tree of the 84 bacterial strains isolated in Cospita Bay oyster and water samples

respectively), followed by Bacillaceae $(8.16 \%)$ and Brucellaceae (25.71\%) in M2 and M3, respectively (Fig. 2).

The number of bacteria species observed exclusively in samples of one oyster species was higher for $C$. sikamea (seven: Vibrio neptunius, $V$. harveyi, $V$. diabolicus, $V$. parahaemolyticus, V. ponticus, $V$. alfacsensis and Bacillus firmus), than for C. corteziensis (four: Vibrio sinaloensis, Bacillus sp., $B$. clausii and Micrococcus yunnanensis). Seven species (families Xanthomonadaceae, Rhodobacteraceae, Staphylococcaceae, Vibrionaceae and Bacillaceae) were found only in water samples (Lysobacter spongicola, Donghicola sp., D. eburneus, Bacillus sp., Staphylococcus cohnii, S. warneii and V. hepatarius) (Table IV).

\section{DISCUSSION}

Silva-Neta et al. (2015) detected higher bacterial concentrations at the end of the dry season, which corresponds to our M1 sampling, while the general tendency to higher bacteria concentrations in oyster tissues in the rainy season, and the correspondingly lower values observed in $C$. corteziensis during the dry season, seem to agree with the direct relationship with water temperature described by Deepanjali et al. (2005) and Aagesen and Häse (2014) for $V$. parahaemolyticus concentrations, or for aerobic heterotrophs and Vibrio-like bacteria determined by Fay et al. (2012).

When they were collected, concentrations of heterotrophic bacteria were higher in wild than in 


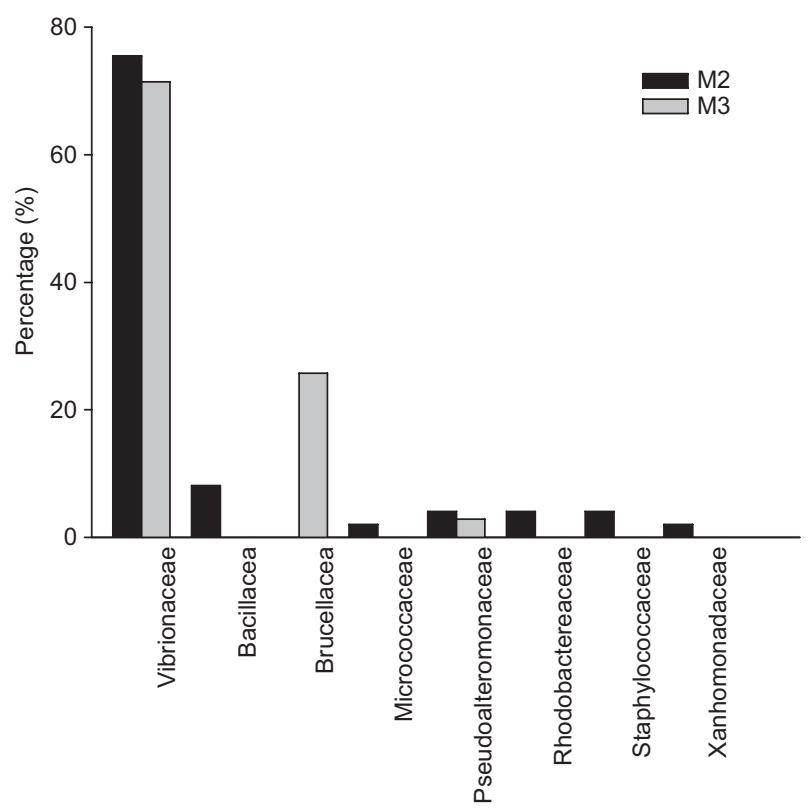

Fig. 2. Bacterial families identified in wild and cultured oysters and in Cospita Bay water samples during the wet-warm season (M2 and M3 samples)

cultured oysters, possibly because of the high levels of organic matter and bacterial concentrations common in their environment (Mahasneh 2001). An additional explanation is the stress caused by tide-dependent exposures (Bishop and Peterson 2006, Farcy et al. 2009), which might have caused an increase in the internal bacterial load. The absence of wild organisms during the rainy period was due to mortalities related to high energy expenditure caused by early summer spawning (Frías-Espericueta et al. 1997) or to stress induced by high temperatures and low salinities. Additionally, summer conditions seem to favor the parasite Perkinsus marinus, whose presence and high incidence was detected in the area object of this study (Cáceres-Martínez et al. 2012, Cáceres-Martínez and Vázquez-Yeomans 2013).

Summer mortalities with similar etiologies have been documented in different geographic areas for several oyster species such as $C$. hongkongensis (Wang et al. 2016), C. gigas (Li et al. 2007), C. virginica (Soniat et al. 2006, Heilmayer et al. 2008) and $C$. ariakensis (Kelly et al. 2011). In all these cases, increasing temperatures would seem to be the driving factor, either causing an increase of energy losses or favoring bacterial or parasite establishment and growth.
Although its presence and abundance should be confirmed with long-term regular observations, the dominance of Vibrionaceae in both oyster species in the warm rainy period coincides with the indication that Vibrio spp. are the most abundant bacteria in oysters during summer months (Pujalte et al. 1999, Wang et al. 2016). Among the species of Vibrio detected in $C$. sikamea, some are known pathogens for invertebrates ( $V$. parahaemolyticus, $V$. hepatarius, $V$. brasilensis, $V$. neptunius and $V$. owensii [Ruangpan and Kitao 1991, Thompson et al. 2003, Cano-Gómez et al. 2010, Rivera-Posada et al. 2011, Gómez-Gil et al. 2012]), while others, such as $V$. xuii, V. ponticus, $V$. alfacsensis and $V$. harveyi may affect vertebrates (Pujalte et al. 2003, Thompson et al. 2003, Xie et al. 2007). Among these pathogens, V. neptunius was isolated in cultures of diseased Nodipecten nodosus larvae (Thompson et al. 2003), and it may cause high mortalities in mussel larvae (Kesarcodi-Watson et al. 2009) and in oyster hatcheries (Prado et al. 2005).

Known pathogens for molluses were not detected in $C$. corteziensis. However, the bacteria $V$. sinaloensis, Micrococcus yunnanensis, Bacillus clausii and $V$. natriegens, which were detected only in this oyster, are known pathogens of Lutjanus guttatus, Litopenaeus vannamei and Acanthaster planci (Gómez-Gil et al. 2008, Flores-Miranda et al. 2011, Rivera-Posada et al. 2011).

Of all known pathogenic Vibrio of major medical interest listed by Daniels and Shafaie (2000), only $V$. parahaemolyticus was present in our oyster samples. Among those isolated from surface waters, the coagulase-negative Staphylococcus warneri and S. cohnii are of mild clinical interest as possible sources of nosocomial infections (Martínez and Máttar 2006, Fariña et al. 2013, Soldera et al. 2013), while Lysobacter spongiicola pertains to a genus of potential importance for its production of several extracellular enzymes (de Bruijn et al. 2015), and because several Lysobacter species have been suggested for biological plant disease control (Hashizume et al. 2004, Li et al. 2008).

\section{ACKNOWLEDGMENTS}

Supported by projects Programa de Fomento y Apoyo a Proyectos de Investigación, PROFAPI 2013/212 and Consejo Nacional de Ciencia y Tecnología, Apoyos a Infraestructura Científica, INFR-2015/251448. D.M. Cruz-Zamudio and G. Solano-Cota helped with the field and analytical work. 
TABLE IV. BACTERIAL STRAINS (M) ISOLATED FROM Crassostrea corteziensis, C.sikamea AND COSPITA BAY WATER SAMPLES

\begin{tabular}{|c|c|c|c|c|}
\hline Strain & Identification & C. corteziensis & C. sikamea & water \\
\hline 182 & Vibrio sp. & M2 & & \\
\hline 183 & Vibrio sp. & M2 & & \\
\hline 187 & Vibrio mediterranei & & M2 & \\
\hline 190 & Vibrio sp. & M2 & & \\
\hline 192 & Vibrio mediterranei & & M2 & \\
\hline 195 & Vibrio sinaloensis & M2 & & \\
\hline 196 & Vibrio neptunius & & M2 & \\
\hline 197 & Vibrio harveyi & & M2 & \\
\hline 200 & Vibrio brasiliensis & M2 & & \\
\hline 201 & Vibrio sp. & & M2 & \\
\hline 203 & Vibrio hepatarius & M2 & & \\
\hline 206 & Vibrio rotiferianus & & M2 & \\
\hline 207 & Vibrio rotiferianus & M2 & & \\
\hline 208 & P. flavipulchra & M2 & & \\
\hline 209 & Lysobacter spongiicola & & & M2 \\
\hline 210 & Donghicola sp. & & & M2 \\
\hline 211 & Bacillus firmus & & M2 & \\
\hline 212 & Vibrio owensii & & M2 & \\
\hline 213 & Vibrio hepatarius & & M2 & \\
\hline 214 & Bacillus sp. & & & M2 \\
\hline 218 & Vibrio diabolicus & & M2 & \\
\hline 220 & Vibrio owensii & M2 & & \\
\hline 222 & Donghicola eburneus & & & $M 2$ \\
\hline 225 & Bacillus sp. & M2 & & \\
\hline 226 & Vibrio harveyi & & M2 & \\
\hline 227 & P. flavipulchra & M2 & & \\
\hline 228 & Vibrio brasiliensis & M2 & & \\
\hline 229 & Vibrio sp. & M2 & & \\
\hline 230 & Vibrio communis & M2 & & \\
\hline 231 & Vibrio brasiliensis & M2 & & \\
\hline 241 & Vibrio harveyi & & M2 & \\
\hline 242 & Vibrio parahaemolyticus & & M2 & \\
\hline 245 & Vibrio communis & & M2 & \\
\hline 247 & Staphylococcus cohnii & & & M2 \\
\hline 248 & Vibrio hepatarius & & & M2 \\
\hline 250 & Vibrio owensii & M2 & & \\
\hline 263 & Micrococcus yunnanensis & M2 & & \\
\hline 267 & Bacillusclausii & M2 & & \\
\hline 300 & Vibrio rotiferianus & M2 & & \\
\hline 302 & Vibrio rotiferianus & & M2 & \\
\hline 303 & Vibrio rotiferianus & & M2 & \\
\hline 305 & Vibrio rotiferianus & M2 & & \\
\hline 311 & Vibrio rotiferianus & & & M2 \\
\hline 315 & Vibrio ponticus & & M2 & \\
\hline 318 & Vibrio rotiferianus & M2 & & \\
\hline 322 & Vibrio communis & M2 & & \\
\hline 327 & Vibrio rotiferianus & M2 & & \\
\hline 328 & Vibrio rotiferianus & M2 & & \\
\hline 330 & Staphylococcus warneri & & & M2 \\
\hline 337 & Vibrio rotiferianus & & M3 & \\
\hline 341 & Vibrio alfacsensis & & M3 & \\
\hline 350 & Vibrio rotiferianus & M3 & & \\
\hline 351 & P. flavipulchra & M3 & & \\
\hline 353 & Vibrio mediterranei & & M3 & \\
\hline 359 & Vibrio brasiliensis & & M3 & \\
\hline
\end{tabular}


TABLE IV. BACTERIAL STRAINS (M) ISOLATED FROM Crassostrea corteziensis, C.sikamea AND COSPITA BAY WATER SAMPLES

\begin{tabular}{|c|c|c|c|c|}
\hline Strain & Identification & C. corteziensis & C. sikamea & water \\
\hline 360 & Vibrio mediterranei & M3 & & \\
\hline 372 & Vibrio rotiferianus & M3 & & \\
\hline 391 & Vibrio mediterranei & M3 & & \\
\hline 394 & Vibrio mediterranei & & M3 & \\
\hline 401 & Vibrio brasiliensis & & M3 & \\
\hline 407 & Vibrio communis & M3 & & \\
\hline 410 & Vibrio sp. & & M3 & \\
\hline 414 & Vibrio owensii & & M3 & \\
\hline 427 & Vibrio communis & & M3 & \\
\hline 437 & Vibrio xuii & & M3 & \\
\hline 457 & Vibrio natriegens & M3 & & \\
\hline 467 & Vibrio communis & M3 & & \\
\hline 468 & Ochrobactrum cytisi & M3 & & \\
\hline 473 & Ochrobactrum cytisi & M3 & & \\
\hline 474 & Ochrobactrum cytisi & M3 & & \\
\hline 475 & Vibrio owensii & M3 & & \\
\hline 479 & Vibrio rotiferianus & M3 & & \\
\hline 481 & Vibrio diabolicus & & M3 & \\
\hline 494 & Ochrobactrum cytisi & M3 & & \\
\hline 500 & Vibrio natriegens & M3 & & \\
\hline 507 & Ochrobactrum cytisi & & M3 & \\
\hline 508 & Vibrio diabolicus & & M3 & \\
\hline 514 & Vibrio rotiferianus & M3 & & \\
\hline 522 & Ochrobactrum cytisi & & M3 & \\
\hline 533 & Ochrobactrum cytisi & M3 & & \\
\hline 561 & Vibrio communis & M3 & & \\
\hline 570 & Vibrio owensii & & M3 & \\
\hline 574 & Ochrobactrum cytisi & M3 & & \\
\hline 576 & Ochrobactrum cytisi & M3 & & \\
\hline
\end{tabular}

\section{REFERENCES}

Aagesen A.M. and Häse C.C. (2014). Seasonal effects of heat shock on bacterial populations, including artificial Vibrio parahaemolyticus exposure, in the Pacific oyster, Crassostrea gigas. Food Microbiol. 38, 93-103. DOI: $10.1016 /$ j.fm.2013.08.008

Altschul S.F. (1997). Evaluating the statistical significance of multiple distinct local alignments. In: Theoretical and computational methods in genome research $(\mathrm{S}$. Suhai, Ed.). Plenum, New York, USA, pp. 1-14.

Beaz-Hidalgo R., Balboa S., Romalde J. and Figueras M. (2010). Diversity and pathogenicity of Vibrio species in cultured bivalve molluscs. Environ. Microbiol. Rep. 2 (1), 34-43. DOI: 10.1111/j.1758-2229.2010.00135.x

Bishop N.J. and Peterson C.H. (2006). Direct effects of physical stress can be counteracted by indirect benefits oyster growth on a tidal elevation gradient. Oecologia 147, 426-433. DOI: 10.1007/s00442-005-0273-3

Cáceres-Martínez J., García-Ortega M., Vásquez-Yeomans R., Pineda-García T.J., Stokes N.A. and Carnegie R.B.
(2012). Natural and cultured populations of the mangrove oyster Saccostrea palmula from Sinaloa, Mexico, infected by Perkinsus marinus. J. Invertebr. Pathol. 110, 321-325. DOI: 10 10.1016/j.jip.2012.03.019

Cáceres-Martínez J. and Vásquez-Yeomans R. (2013). Enfermedades, parásitos y episodios de mortalidad de ostiones de importancia comercial en México y sus implicaciones para la producción. Ciencia Pesquera $21,5-48$.

Cano-Gómez A., Goulden E.F., Owens L. and Høj L. (2010). Vibrio owensii sp. nov., isolated from cultured crustaceans in Australia. FEMS Microbiol. Lett. 302 (2), 175-181. DOI: 10.1111/j.1574-6968.2009.01850.x

Cheney D.P., MacDonald B.F. and Elston R.A. (2000). Summer mortality of Pacific oyster, Crassostrea gigas (Thunberg): Initial findings on multiple environmental stressors in Puget Sound, Washington, 1998. J. Shellfish Res. 19, 353-359.

Chun J., Lee J.H., Jung Y., Kim M., Kim S., Kim B.K. and Lim Y.W.( 2007). EzTaxon: A webbased tool for the identification of prokaryotes based on $16 \mathrm{~S}$ ribosomal 
RNA gene sequences. Int. J. Syst. Evol. Microbiol. 57, 2259-2261. DOI: 10.1099/ijs.0.64915-0

CONAPESCA (2013). Anuario estadístico de acuacultura y pesca 2013. Secretaría de Agricultura, Ganadería, Desarrollo Rural, Pesca y Alimentación, Comisión Nacional de Acuacultura y Pesca. Mazatlán, Mexico, 299 pp.

Conover W.J. (2012). The rank transformation-an easy and intuitive way to connect many nonparametric methods to their parametric counterparts for seamless teaching introductory statistics courses. WIREs Comp. Stat. 4, 432-438. DOI: $10.1002 /$ wics. 1216

Daniels N.A. and Shafaie A. (2000). A review of pathogenic Vibrio infections for clinicians. Infect. Med. 17 (10), 665-685

Daniels N.A., MacKinnon L., Bishop R., Altekruse S., Ray B., Hammond R.M., Thompson S., Wilson S., Bean N.H., Griffin P.M. and Slutsker L. (2000). Vibrio parahaemolyticus infections in the United States, 1973-1998. J. Infect. Dis. 181, 1661-1666.

\section{DOI: $10.1086 / 315459$}

De Bruijn I., Cheng X., de Jager V., Gómez Expósito R., Watrous J., Patel N., Postma, J., Dorrestein P.C., Kobayashi D. and Raaijmakers J.M. (2015). Comparative genomics and metabolic profiling of the genus Lysobacter. BMC Genomics 16, 991.

DOI: 10.1186/s12864-015-2191-z

Deepanjali A., Kumar H.S., Karunasagar I. and Karunasagar I. (2005). Seasonal variation in abundance of total and pathogenic Vibrio parahaemolyticus bacteria in oysters along the southwest coast of India. App. Environ. Microbiol. 71, 3575-3580.

DOI: 10.1128/AEM.71.7.3575-3580.2005

De Decker S. and Saulnier D. (2011). Vibriosis induced by experimental cohabitation in Crassostrea gigas: Evidence of early infection and down-expression of immune related genes. Fish Shellfish Immunol. 30, 691-699. DOI: 10.1016/j.fsi.2010.12.017

Farcy E., Voiseux C., Lebel J.-M. and Fiévet B. (2009). Transcription genes in the Pacific oyster exposed to acute thermal stress. Cell Stress Chaperones 14, 371380. DOI: $10.1007 / \mathrm{s} 12192-008-0091-8$

Fariña N., Carpinelli L., Samudio M., Guillén R., Laspina F., Sanabria R., Abente S., Rodas L., González P. and de Kaspar H.M. (2013). Staphylococcus coagulasanegativa clínicamente significativos. Especies más frecuentes y factores de virulencia. Rev. Chil. Infectol. 30, 480-488. DOI: 10.4067/S0716-10182013000500003

Fay P.J., Richards G.P. and Ozbay G. (2012). Water quality parameters and total aerobic bacterial and Vibrionaceae loads in eastern oysters (Crassostrea virginica) from oyster-gardening sites. Arch. Environ. Contam. Toxicol. 62, 628-637. DOI: 10.1007/s00244-011-9736-1
Flores-Miranda M.C., Luna-González A., Campa-Córdova Á.I., González-Ocampo H.A., Fierro-Coronado J.A. and Partida-Arangure B.O. (2011). Microbial immunostimulants reduce mortality in whiteleg shrimp (Litopenaeus vannamei) challenged with Vibrio sinaloensis strains. Aquaculture 320, 51-55.

DOI: 10.1016/j.aquaculture.2011.08.005

Frías-Espericueta M.G., Páez-Osuna F. and Osuna-López J.I. (1997). Seasonal changes in the gonadal state of the oysters Crassostrea iridescens and Crassostrea corteziensis (Filibranchia: Ostreidae) in the Northwest coast of Mexico. Rev. Biol. Trop. 45, 1061-1065.

García-Lázaro M., Almodóvar-Pulido M.C., Rivero A. and Torre-Cisneros J. (2010). Cólera y otras infecciones del género Vibrio. Medicine 11 (56), 3317-3321. DOI: $10.1016 / \mathrm{S} 0304-5412(14) 70776-0$

Garnier M., Labreuche Y., Garcia C., Robert M. and Nicolas J.L. (2007). Evidence for the involvement of pathogenic bacteria in summer mortalities of the Pacific oyster Crassostrea gigas. Microb. Ecol. 53 (2), 187-196. DOI: 10.1007/s00248-006-9061-9

Garnier M., Labreuche Y. and Nicolas J.L. (2008). Molecular and phenotypic characterization of Vibrio aestuarianus subsp. francensis subsp. nov., a pathogen of the oyster Crassostrea gigas. Syst. Appl. Microbiol. 31 (5), 358-365.

DOI: $10.1016 /$ j.syapm.2008.06.003

Gay M., Renault T., Pons A.M. and Le Roux F. (2004). Two Vibrio splendidus related strains collaborate to kill Crassostrea gigas: taxonomy and host alterations. Dis. Aquat. Org. 62, 65-74. DOI: 10.3354/dao062065

Gómez-Gil B., Fájer-Ávila E., Pascual J., Macián M.C., Pujalte M.J., Garay E. and Roque A. (2008). Vibrio sinaloensis sp. nov., isolated from the spotted rose snapper, Lutjanus guttatus Steindachner, 1869. Int. J. Syst Evol. Microbiol. 58(7), 1621-1624.

DOI: 10.1099/ijs.0.65719-0

Gómez-Gil B., Roque A., Chimetto L., Moreira A.P.B., Lang E. and Thompson F.L. (2012). Vibrio alfacsensis sp. nov., isolated from marine organisms. Int. J. Syst. Evol. Microbiol. 62 (12), 2955-2961.

DOI: 10.1099/ijs.0.033191-0

Harekrishna J., Keshab C., Mondal, Maity C., Das A., Halder S.K. and Mitra A. (2014). Effect of microbial load on the condition index of the edible oyster, Saccostrea cucullata in the Sundarbans. India. Int. J. Aquat. Biol. 2, 238-245.

Hashizume H., Hirosawa S., Sawa R., Muraoka Y., Ikeda D., Naganawa H. and Igarashi M. (2004). Tripropeptins, novel antimicrobial agents produced by Lysobacter sp. J. Antibiot. (Tokyo) 57, 52-58.

Heilmayer O., Digialleonardo J., Qian L. and Roesijadi G. (2008). Stress tolerance of a subtropical Crassostrea 
virginica population to the combined effects of temperature and salinity. Est. Coast. Shelf Sci. 79, 179-185. DOI: 10.1016/J.ECSS.2008.03.022

Kelly C.J., Laramore S.E., Scarpa J. and Newell R.I.E. (2011). Seasonal comparison of physiological adaptation and growth of suminoe (Crassostrea ariakensis) and eastern (Crassostrea virginica) oysters. J. Shellfish Res. 30, 737-749. DOI: 10.2983/035.030.0314

Kesarcodi-Watson A., Kaspar H., Lategan M.J. and Gibson L. (2009). Two pathogens of greenshell mussel larvae, Perna canaliculus: Vibrio splendidus and a $V$. coralliilyticus/neptunius-like isolate. J. Fish Dis. 32 (6), 499-507. DOI: 10.1111/j.1365-2761.2009.01006.x

Kokashvili T., Whitehouse C.A., Tskhvediani A., Grim C.J., Elbakidze T., Mitaishvili N., Janelidze N., Jaiani E., Haley B.J., Lashkhi N., Huq A., Colwell R.R. and Tediashvili M. (2015). Occurrence and diversity of clinically important Vibrio species in the aquatic environment of Georgia. Front. Pub. Health 3, 232. DOI: $10.3389 /$ fpubh.2015.00232

Labreuche Y., Le-Roux F., Henry J., Zatylny C., Huvet A., Lambert C., Soudant P., Mazel D. and Nicolas J.L. (2010). Vibrio aestuarianus zinc metalloprotease causes lethality in the Pacific oyster Crassostrea gigas and impairs the host cellular immune defenses. Fish Shellfish Immunol. 29, 753-758.

DOI: $10.1016 /$ j.fsi.2010.07.007

Li Y., Qin J.G., Abbott C.A., Li X. and Benkendorff K. (2007). Synergistic impacts of heat shock and spawning on the physiology and immune health of Crassostra gigas: An explanation for summer mortality in Pacific oyster. Am. J. Physiol. Regul. Integr. Comp. Physiol. 293 (6), 2353-2362. DOI: 10.1152/ajpregu.00463.2007

Li S., Jochum C.C., Yu F., Zaleta-Rivera K., Du L., Harris S.D. and Yuen G.Y. (2008). An antibiotic complex from Lysobacter enzymogenes strain C3: Antimicrobial activity and role in plant disease control. Phytopathology 98, 695-701. DOI: 10.1094/PHYTO-98-6-0695

Llanos J., Cid M., Navarro S., Dinamarca A. and GarcíaTello P. (2002). Atypical bacteria accompanying the scallop Argopecten purpuratus. Invest. Mar. 30(2), 57-59. DOI: $10.4067 / \mathrm{S} 0717-71782002000200005$.

Mahasneh A.M. (2001). Seasonal incidence of some heterotrophic aerobic marine bacteria in an Avicennia marina habitat along a Qatari Coast. J. Biol. Sci. 1(7), 666-670. DOI: $10.3923 / \mathrm{jbs} .2001 .666 .670$

Martínez P. and Máttar S. (2006). Posible aislamiento clínico de Staphylococcus cohnii resistente a vancomicina: reporte de caso. Infectio 10 (3), 175-177.

McLaughlin J.B., DePaola A., Bopp C.A., Martinek K.A., Napolilli N.P., Allison C.G., Murray S.L., Thompson E.C., Bird M.M. and Middaugh J.P. (2005). Outbreak of Vibrio parahaemolyticus gastroenteritis associated with Alaskan oysters. N. Engl. J. Med. 353, 1463-1470 DOI: 10.1056/NEJMoa051594

Paillard C., LeRoux F. and Borrego J.J. (2004). Bacterial disease in marine bivalves, a review of recent studies: trends and evolution. Aquat. Living Res. 17, 477-498. DOI: 10.1051/alr:2004054

Petton B., Bruto M., James A., Labreuche Y., AlunnoBruscia M. and Leroux F. (2015). Crassostrea gigas mortality in France: The usual suspect, a herpesvirus, may not be the killer in this polymicrobial opportunistic disease. Front. Microbiol. 6, 686.

DOI: $10.3389 /$ fmicb.2015.00686

Prado S., Romalde J.L., Montes J. and Barja J.L. (2005). Pathogenic bacteria isolated from disease outbreaks in shellfish hatcheries. First description of Vibrio neptunius as an oyster pathogen. Dis. Aquat. Org. 67(3), 209-215. DOI: 10.3354/dao067209

Pujalte M.J., Ortigosa M., Macian M.C. and Garay E. (1999). Aerobic and facultative anaerobic heterotrophic bacteria associated to Mediterranean oysters and seawater. Int. Microbiol. 2, 259-266.

Pujalte M.J., Sitjà-Bobadilla A., Macián M.C., Belloch C., Alvarez-Pellitero P., Pérez-Sánchez J., Uruburu F. and Garay E. (2003). Virulence and molecular typing of Vibrio harveyi strains isolated from cultured dentex, gilthead sea bream and European sea bass. Syst. Appl. Microbiol. 26(2), 284-292.

DOI: $10.1078 / 072320203322346146$

Rivera-Posada J.A., Pratchett M., Cano-Gómez A., Arango-Gómez J.D. and Owens L. (2011). Refined identification of Vibrio bacterial flora from Acanthasther planci based on biochemical profiling and analysis of housekeeping genes. Dis. Aquat.Org. 96 (2), 113-123. DOI: $10.3354 /$ dao02389

Romanenko L.A., Uchino M., Kalinovskaya N.I. and Mikhailova V.V. (2008). Isolation, phylogenetic analysis and screening of marine mollusc-associated bacteria for antimicrobial, hemolytic and surface activities. Microbiol. Res. 163, 633-644.

DOI: 10.1016/j.micres.2006.10.001

Ruangpan L. and Kitao T. (1991). Vibrio bacteria isolated from black tiger shrimp, Penaeus monodon Fabricius. J. Fish Dis. 14 (3), 383-388. DOI: 10.1111/j.1365-2761.1991.tb00836.x

Saitou N. and Nei M. (1987). The neighbor-joining method: A new method for reconstructing phylogenetic trees. Mol. Biol. Evol. 4, 406-425.

Samain, J.F. and McCombie H. (Eds.) (2008). Summer mortality Pacific oyster Crassostrea gigas: The Morest Project. Éditions Quae, Versailles, France, 379 pp.

Saulnier D., Decker S.D., Haffner P., Cobret L., Maeva R., Garcia C. (2010). A large-scale epidemiological study to identify bacteria pathogenic to Pacific oyster 
Crassostrea gigas and correlation between virulence and metalloprotease-like activity. Microb. Ecol. 59, 787-798. DOI: 10.1007/s00248-009-9620-y

Silva-Neta M.T., Maciel B.M, Lopes A.T.S., Marques E.L.S., Rezende R.P., and Boehs G. (2015). Microbiological quality and bacterial diversity of the tropical oyster Crassostrea rhizophorae in a monitored farming system and from natural stocks. Genet. Mol. Res. 14, 15754-15768. DOI: 10.4238/2015.December.1.27 Soldera J., Nedel W.L., Cardoso P.R. and d'Azevedo P.A. (2013). Bacteremia due to Staphylococcus cohnii ssp. urealyticus caused by infected pressure ulcer: case report and review of the literature. Sao Paulo Med. J. 131 (1), 59-61. DOI: 10.1590/S1516-31802013000100010 Soniat T.M., Klinck J.M., Powell E.N. and Hoffmann E.E. (2006). Understanding the success and failure of oyster populations: Climatic cycles and Perkinsus marinus. J. Shellfish Res. 25, 83-93.

DOI: 10.2983/0730-8000(2006)25[83:utsafo]2.0.co;2

Tamura K., Peterson D., Peterson N., Stecher G., Nei M., and Kumar S. (2011). MEGA5: molecular evolutionary genetics analysis using maximum likelihood, evolutionary distance, and maximum parsimony methods. Mol. Biol. Evol. 28 (10), 2731-2739. DOI: 10.1093/ molbev/msr121

Thompson F.L., Li Y., Gomez-Gil B., Thompson C.C., Hoste B., Vandemeulebroecke K., Rupp G.S., Pereira A., De Bem M.M., Sorgeloos P. and Swings J. (2003). Vibrio neptunius sp. nov., Vibrio brasiliensis sp. nov. and Vibrio xuii sp. nov., isolated from the marine aquaculture environment (bivalves, fish, rotifers and shrimps). Int. J. Syst. Evol. Microbiol. 53, 245-252. DOI: 10.1099/ijs.0.02447-0

Thompson J.D., Higgins D.G. and Gibson T.J. (1994). CLUSTAL W: improving the sensitivity of progressive multiple sequence alignment through sequence weighting, position-specific gap penalties and weight matrix choice. Nucleic Acids Res. 22 (22), 4673-4680.

Trabal-Fernández N., Mazón-Suástegui J.M., VázquezJuárez R., Ascencio-Valle F. and Romero J. (2014). Changes in the composition and diversity of the bacterial microbiota associated with oyster (Crassostrea corteziensis, Crassostrea gigas and Crassostrea sikamea) during commercial production. FEMS Microbiol. Ecol. 88, 69-88. DOI: 10.1111/1574-6941.12270

Wang R., He J. and Wang J. (2016). Heterotrophic bacterial abundance and diversity in the farming environment and guts of the oyster Crassostrea hongkongensis. J. Shellfish Res. 35, 343-350. DOI: $10.2983 / 035.035 .0208$

Xie Z.Y., Hu C.Q., Zhang L.P., Chen C., Ren C.H. and Shen Q. (2007). Identification and pathogenicity of Vibrio ponticus affecting cultured Japanese sea bass, Lateolabrax japonicas (Cuvier in Cuvier and Valenciennes). Lett. Appl. Microbiol. 45 (1), 62-67. DOI: $10.1111 / j .1472-765 X .2007 .02141 . x$

Zar J.H. (1996). Biostatistical analysis. Prentice-Hall, Englewood Cliffs, New Jersey, USA, 620 pp. 